\title{
Animação em aula: Os heróis dos desenhos animados no ensino de história.
}

\author{
Mario Marcello Neto ${ }^{1}$
}

\section{Resumo:}

Este trabalho é resultado de pesquisas em andamento sobre o uso de desenhos animados como fontes no Ensino de História. Ao iniciarmos os estudos acerca do tema, nos deparamos com inúmeras relações entre os Quadrinhos e os Desenhos Animados. A mais significativa perpetuação de elementos presentes nas HQ's representada nos quadrinhos é a imagem do Herói. Aqui, Através da análise do desenho produzido pela DC Comics, Liga da Justiça (2001), tentaremos estabelecer relações destes elementos que acabam formando o imaginário social de uma parcela da sociedade. Para isso, além da análise dos desenhos supracitados, foi feita uma densa revisão bibliográfica, permitindo que este trabalho obtivesse um aporte teórico suficiente para problematizar o tema.

Palavras-Chave: Desenhos Animados, Ensino de História, Imagens, Heróis, Representação, Imaginário.

\section{Explicando o Tema}

Este texto pretende tratar atividades realizadas através do Programa Institucional de Bolsas de Iniciação a Docência (PIBID/

1 Graduando do $5^{\circ}$ Semestre do curso de Licenciatura em História pela Universidade Federal de Pelotas - UFPel. Bolsistas no Programa Institucional de Bolsas de Iniciação a Docência - PIBID - Humanidades - UFPel / CAPES. mariomarceloneto@yahoo.com.br 
Humanidades - UFPel), o qual estamos inseridos. Este tem como principal proposta de atividade a utilização do cinema como fonte histórica e a sua inclusão no ensino de história. Sendo assim, iniciou-se um período de estudos acerca do tema. Observou-se que a discussão sobre o uso de imagens, de um modo geral, no ensino desta disciplina vem sendo problematizado. Livros didáticos da década de 1930, por exemplo, faziam propagandas em suas capas por possuírem imagens ilustrativas, numa tentativa de aproximar a imagem tão presente na realidade do aluno ao seu cotidiano escolar (FONSECA, 2006).

Após leituras prévias, como CHARTIER (2010), FUSARI (1985), ECO (2004), notou-se, também, que o uso do cinema e televisão como recurso didático e como fonte histórica não é algo recente no Ensino de História. Autores como NAPOLITANO (2010), VALIM (2007), CASTRO (2010), HAGEMEYER (2012), têm em suas obras excelentes discussões sobre estes assuntos. Porém, uma temática que, normalmente, passa em branco nessas discussões sobre imagens, mídias e ensino é o Desenho Animado. Este trabalho tentará fazer relações deste ensino, que necessita utilizar a linguagem visual e digital do mundo do aluno em sala de aula. Um ensino que dialogue com a realidade digital e imagética a qual os discentes estão inseridos (BELLONI, 2001).

A primeira dificuldade encontrada neste processo de estudos e pesquisas foi encontrar referencias bibliográficas que 
pudessem dialogar diretamente sobre Desenhos Animados e Ensino de História. Devido a essa dificuldade em encontrar referencias específicas sobre o tema, buscamos estudos em duas mídias que em muito se assemelham aos Desenhos, seja por roteiros semelhantes no caso das Histórias em Quadrinhos - seja por técnicas que inspiraram sua construção no caso o cinema. Um autor, especificamente, irá embasar este trabalho em relação a justificativa do porque o uso dos desenhos animados em sala de aula é importante: Marcos Napolitano. Ele irá comentar sobre o cinema, porém, fazendo devidas adaptações poderemos ter questionamentos importantes sobre o tema. Sobre o cinema no ensino de História, Napolitano afirma:

Trabalhar com o cinema em sala de aula é ajudar a escola a reencontrar a cultura ao mesmo tempo cotidiana e elevada, pois o cinema é o campo no qual a estética, o lazer, a ideologia e os valores sociais mais amplos são sintetizados numa mesma obra de arte. (NAPOLITANO, 2010: 11)

Se trocarmos a terceira palavra da citação acima "cinema" por "desenhos animados" conseguiremos entender que o cinema traz consigo toda aquela carga político-ideológica que o seu contexto histórico permite. E assim funciona com os desenhos animados. Embora tenham o objetivo de entreter e de serem de pequena duração, trazem em sua linguagem um modo de ver e entender a sociedade vigente, para um público jovem, que está 
formando o seu caráter, seus ideais, que necessita de exemplos, que em muitos casos vão ser sim, os desenhos animados. Napolitano, vai além de comentar os benefícios que o cinema/desenho animado tem em relação à incorporação dos valores da sociedade em que foi produzido. Ele vai argumentar, também, sobre a maneira pela qual estão sendo trabalhados em sala de aula. O autor vai problematizar o fato de que:

É preciso que a atividade escolar com o cinema vá além da experiência cotidiana, porém sem negá-la. A diferença é que a escola, tendo o professor como mediador, deve propor leituras mais ambiciosas além do puro lazer, fazendo a ponte entre emoção e razão de forma mais direcionada, incentivando o aluno a se tornar um espectador mais exigente e crítico, propondo relações de conteúdo/linguagem do filme com o conteúdo escolar. (NAPOLITANO, 2010: 15)

Segundo Maria Felisminda de Rezende e Fusari (1985), o desenho animado é uma mídia de grande difusão e aceitação na sociedade, principalmente em relação ao público jovem. O Desenho Animado, de um modo geral, possui uma linguagem universal, ou seja, adaptável a todo público-alvo, utilizando o humor e enredos que permitam uma maior compreensão de uma realidade própria da Animação. Os Desenhos sobre Heróis, por sua vez, reconstroem na sociedade algo que tomou proporções até então inimagináveis, reafirmando o Imaginário Social (BACKZO, 1985) já existente sobre eles desde a criação de Quadrinhos sobre este gênero. Nos decorrer do texto abordaremos de forma mais explicita a forma com 
a qual as atividades realizadas pelo PIBID, o uso de Desenhos Animados de Herois e a metodologia aplicada sobre este recurso são o principal foco deste texto.

\section{Entendendo os Conceitos}

Iniciando o processo de entendimento de alguns conceitos a respeito da temática em questão, temos que hoje só é possível tratar os Desenhos Animados como fontes históricas no Ensino de História, devido a uma mudança na concepção deste conceito, nas primeiras décadas do século XX. Esta mudança a qual nos referimos, trata-se da alteração e ampliação deste conceito supracitado. Durante a chamada primeira geração da Escola dos Annales, seus principais historiadores defendiam a tese de ampliação total do conceito de fonte. Passado a ser reconhecido como fonte histórica todo o vestígio deixado pelo homem. José D’assunção Barros diz que:

"Fonte Histórica" é tudo aquilo que, produzido pelo homem ou trazendo vestígios de sua interferência, pode nos proporcionar um acesso à compreensão do passado humano. Neste sentido, são fontes históricas tanto os já tradicionais documentos textuais (crônicas, memórias, registros cartoriais, processos criminais, cartas legislativas, obras de literatura, correspondências públicas e privadas e tantos mais) como também quaisquer outros que possam nos fornecer um testemunho ou um discurso proveniente do passado humano, da realidade um dia vivida e que se apresenta como relevante para o Presente do historiador. (BARROS, 2011). 
Segundo essa concepção metodológica da História, o Desenho Animado também pode ser utilizado como fonte histórica, afinal ele é fruto da construção do homem, deixando rastros muito marcantes sobre o seu contexto de criação. A difusão destes Desenhos através da televisão, hoje, é algo que torna-o muito popular, porém por possuir uma linguagem sensível e adocicada pelo humor, muitas vezes, passa despercebido de todas as Representações feitas sobre sociedade. Desde discursos antiterroristas, anarquistas, comunistas até questões de igualdade sexual e racial, bem como temas envolvendo religião são facilmente encontrados nas animações de maneiras muito suave, com uma forma muito sutil de passar um recado sobre o que está realmente se propondo a dizer. Além disso, não podemos negar que todas estas questões são frutos; evidentemente; de nossa sociedade, onde as questões do presente sempre estarão incluídas em qualquer obra feita pelo homem, não importando ela qual seja (BARROS, 2010).

Todavia, para trabalhar com Desenho Animado em uma aula de história é necessário, além da noção de fonte histórica a ampliação de seu conceito e sua importância, que se entenda os inúmeros fatores que envolvem todo o processo de desenvolvimento e criação da obra. É essencial, também, que se entenda que uma animação não reflete e nem retrata nenhum período histórico, ela Representa o mesmo. Para Chartier: Representações: 
Cadernos de Clio, Curitiba, n. ${ }^{\text {o } 3,2012}$

[...] não são simples imagens, verdadeiras ou falsas, de uma realidade que lhes seria externa; elas possuem uma energia própria que leva a crer que o mundo ou o passado é efetivamente, o que dizem que é. (CHARTIER, 2010: 51).

Sobre a questão de não refletir e nem retratar, Chartier comenta que por mais verossímil a obra em questão seja com a realidade, ela jamais será fiel ao fato acontecido. Isso ocorre devido a subjetividade implicada na percepção desta realidade. Para mim, uma fato ocorrido aconteceu de um determinado ângulo, de certa maneira, para outra pessoa foi de uma forma completamente diferente; e assim por diante. Além disso, esse tipo de Representação da sociedade nos permite dizer que os Desenhos Animados nos transportam para outra realidade, que nos transmite a verdade que ele mesmo constrói. Como Chartier afirma os Desenhos não são simples imagens de outra realidade, ele compõe uma realidade própria, possuem aquela energia que faz com que a sociedade realmente aceite a sua história passando a vê-la da forma como realmente ele diz que é.

Isto, no caso de Desenhos Animados de Herois, deixa evidente que para existir uma grande aceitação do público para com estes personagens não bastariam apenas a sua realidade construída sem nenhuma relação com a concepção nossa de realidade. A realidade dos Super-Herois são sim a nossa realidade, vivemos em um mundo de características muito semelhantes, embora elementos 
considerados fantásticos, como seres de outros planetas entre outras coisas existam com muita frequência, sabe-se que a aproximação com o cotidiano do público leitor/espectador é mais do que necessária para que a identificação possa ser realizada de uma maneira mais rápida, O Super-Homem, por exemplo, de acordo com Umberto Eco (2004) é o sonho, de grande parte, do povo americano do período, ou seja, um fazendeiro que estuda e vai trabalhar em um veículo de mídia, mas que simplesmente retirando seus óculos torna-se tudo o que aquela sociedade precisa.

Os heróis são incapazes de ferir sentimentos de alguém sem se culparem posteriormente, são intelectualizados, dispostos e acima de tudo possuem um caráter universalista de ajudar o próximo, muito mais do que a si (VIANA, 2005); como é possível notar na análise dos desenhos animados: Liga da Justiça (2001). Algumas características são muito comuns aos Herois do chamado Universo DC; a bondade, altruísmo, espírito de justiça são elementos comuns a, quase, todos os Herois desta produtora. Umberto Eco comenta sobre o Super-Homem, analisando justamente esta questão em relação do homem com o Heroi. Esta relação é importante de ser entendida, pois ao termos em mente que função um herói exerce em nossa sociedade, foi possível estabelecer com os alunos um dialogo mais concreto sobre o tema, discutindo as questões com um olhar diferenciado daquela mito criado sobre os Super-Herois. Sobre isso, Eco comenta que: 
O Superman é o mito típico de tal gênero de leitores: o Superman não é um terráqueo, mas chegou à Terra, ainda menino, vindo do planeta Crípton. Crípton estava para ser destruído por uma catástrofe cósmica e o pai do Superman, hábil cientista, conseguira pôr o filho a salvo, confiando-o a um veículo espacial. Crescido na Terra, o Superman vê-se dotado de poderes sobrehumanos. Sua força é praticamente ilimitada, ele pode voar no espaço a uma velocidade igual à da luz, e quando ultrapassa essa velocidade atravessa a barreira do tempo, e pode transferir-se para outras épocas. Com a simples pressão das mãos, pode submeter o carbono a uma tal temperatura que o transforma em diamante; em poucos segundos, a uma velocidade supersônica, pode derrubar uma floresta inteira, transformar árvores em toros e construir com eles uma aldeia ou um navio; pode perfurar montanhas, levantar transatlânticos, abater ou edificar diques; seus olhos de raios X permitem-lhe ver através de qualquer corpo, a distâncias praticamente ilimitadas, fundir com o olhar objetos de metal; seu superouvido coloca-o em condições vantajosíssimas, permitindo-lhe escutar discursos de qualquer ponto que provenham. E belo, humilde, bom e serviçal: sua vida é dedicada à luta contra as forças do mal e a polícia tem nele um colaborador incansável.

Todavia, a imagem do Superman não escapa totalmente às possibilidades de identificação por parte do leitor. De fato, o Superman vive entre os homens sob as falsas vestes do jornalista Clark Kent; e, como tal, é um tipo aparentemente medroso, tímido, de medíocre inteligência, um pouco embaraçado, míope, súcubo da matriarcal e mui solícita colega Míriam Lane, que, no entanto, o despreza, estando loucamente enamorada do Superman. Narrativamente, a dupla identidade do Superman tem uma razão de ser, porque permite articular de modo bastante variado a narração das aventuras do nosso herói, os equívocos, os lances teatrais, um certo suspense próprio de romance policial. Mas, do ponto de vista mitopoiético, o 
Cadernos de Clio, Curitiba, n. ${ }^{\circ}$ 3, 2012

achado chega mesmo a ser sapiente: de fato, Clark Kent personaliza, de modo bastante típico, o leitor médio torturado por complexos e desprezado pelos seus semelhantes; através de um óbvio processo de identificação, um accountant qualquer, de uma cidade norte-americana qualquer, nutre secretamente a esperança de que um dia, das vestes da sua atual personalidade, possa florir um super-homem capaz de resgatar anos de mediocridade. (ECO, 2004: 247248)

A citação acima permite compreender como um Herói deve se portar, ou seja, não basta que ele tenha super-poderes, ele deve, também, manter uma relação de naturalidade com o seu público-alvo. Isso faz com que ele torna-se mais humano, dando o tom de realidade necessário para o convencimento do público. Além disso, Eco nos remete outra possibilidade de discussão com relação aos Super-Herois que a questão da Identidade Secreta como forma de identificação para com o público leitor, no caso dos Desenhos expectador. O Super-Homem, embora seja um ser de outro planeta que ao chegar bebê na Terra é criado por fazendeiros, quando se descobre com super-poderes ele se destaca perante os meros mortais.

A relação de um homem que comum, um jornalista que tem muito azar em relacionamentos amorosos, mas que ao retirar os óculos se transforma num dos Herois mais forte de toda a História, causa um relação completamente diferenciada de qualquer outro tipo de personagem fictício. Como Eco afirma, no trecho supracitado, isso acaba gerando no público ao qual tem contato com 
o mesmo uma sensação que num simples ato de mudar as suas vestes saiam de sua vida comum e semelhante a todos e se tornem um Super-Homem.

Ao compreendermos de maneira mais aprofundada esta ideia de Eco, conseguimos iniciar um processo de amadurecimento sobre o que pretendíamos realizar na escola. Buscamos ao longo de toda a oficina mostrar uma outra forma, que não a idealizada, do Heroi, mostrando como esta relação humana e sobre-humano conseguem dialogar de forma tão implícita a se confundir uma realidade fictícia com a própria realidade.

\section{O nascimento da Detective Comics}

Esta parte do texto, ajudará a entender, entre outras coisa, o motivo pelo qual resolvemos realizar o nosso recorte sobre Desenhos Animados de Super-Herois e mais especificamente o porque da escolha da Liga da Justiça (2001). As chamadas Eras ${ }^{2}$ dos quadrinhos produzidos pela DC Comics foram se adaptando de acordo com a necessidade da sociedade da época. O mito do Herói dos quadrinhos e depois das animações, criado na década de 1920, ganha as mesmas características quando passa a ser exibido pela

2 Sobre isso ver o Documentário comemorativo dos 70 anos da DC Comics: "Secret Origin The Story of DC Comics" (2010); onde personalidades do mundo da animação, como Neal Adams, Neil Gaiman, Len Wein, Denny O’Neill, Jim Lee, Grant Morrison e outros, dão sua contribuição para contar esta saga da editora que praticamente inventou os super-heróis como nós conhecemos hoje. 
televisão. Ao contexto de criação desses personagens pode-se definir ao caos social que o Crack da Bolsa de Valores de 1929 causou nos Estados Unidos Da América e no Mundo. Os problemas sociais internos como roubos, desemprego, fome entre outros temas são os principais alvos do combate destes heróis. Segundo depoimento de Mark Waid, escritor de quadrinho da DC Comics, no documentário: Secret Origin The Story of DC Comics (2010) afirma que:

Dá para contar nos dedos de uma mão os personagens de gibis que foram criados por pessoas bem-sucedidas. Os personagens de longevidade sempre surgem da opressão. Sempre vem de alguém que quer sair do mundo onde está. Todos nós éramos garotos do Bronx.(Secret Origin The Story of DC Comics, 2010. 15:39,828-15:58,349)

Irwin Hasen, artista da DC Comics, no mesmo documentário supracitado, ratifica dizendo que:

Todos nós éramos um bando de tolos, um bando de tolos judeus. Éramos inocentes, talentosos e tolos. Nós nunca desenhávamos a nós mesmos. Por quê? Por que desenharíamos pobres? O que nos inspiraria a desenhar pobres? A indústria de gibis é feita de pessoas que não são aceitas e que querem muito ser aceitas. Eles queriam muito virar tendência nos EUA. Por isso Batman é um milionário e Super Homem é um fazendeiro. Queriam ser tendência real mesmo, dos EUA reais. Então, eles viram marcas em imagens heróicas que personificam tudo o que eles queriam ser. Ricos, bonitos, musculosos capazes de lidar com qualquer situação e desembaraçados. (Secret Origin The Story of DC Comics,2010. 00:15:58,646 00:17:02,446) 
Nos trechos supracitados, podemos notar uma clara relação entre o criador, a obra e quem compra a mesma. Para ambos os entrevistados acima, como para Viana (2005), o comum não é tão vendável quanto o incomum. Se pararmos para pensar que os Herois dos Quadrinhos são criados por pobres em um contexto de extrema miséria nos Estados Unidos da América; fica evidente que roteiros sobre pessoas ou Herois de mesma origem não trariam algo de novo para o mercado, por isso, vê-se a necessidade de utilizar-se do artifício do sonho concretizado em uma obra artística. Aquilo que Eco reconhece como uma forma de auto-afirmação, na qual o criador se projeta em sua criação. Isto nos permite dizer que os Herois da DC Comics, que surgiram na década de 1920 até a década de 1940, caracterizam-se por homens bem sucedidos financeiramente, mas que mesmo assim, tem poderes sobrenaturais que permitem a eles ajudar ao próximo.

Uma informação importante a qual Hadju (2008) comenta, é que os Quadrinho, no período em que os Herois foram criados era o meio de diversão visual mais barato existente. Considerado por ele uma das maiores invenções do Século XX. As HQ’s custavam em torno de dez centavos de Dollar, um valor baixo para o período, fato que ajudou, e muito a popularizar uma forma de entretenimento como esta. Os Comics Books, como são chamados os quadrinhos na língua inglesa, alcançaram vendas de tiragens realmente altas para os padrões aos quais estavam acostumados. Afinal eram feitos 
justamente para os maiores consumidores dos EUA no período, os trabalhadores alfabetizados. Sobre isso, René Jarcem (2007) auxilia na compreensão deste contexto de surgimento desses Heróis.

O Batman, o Homem-Morcego, e a Mulher Maravilha foram criados logo em seguida ao final do primeiro ciclo, o chamado de a Era de Ouro dos quadrinhos. Batman foi o primeiro Herói a não ter poderes, porém suas características pessoas - não possui medo, é sagaz e muito inteligente - e destreza com relação as artes marciais e apoio da tecnologia de seus equipamentos o tornou um dos personagens preferidos dos consumidores.

Durante a Segunda Guerra Mundial, principalmente após o ataque a Perl Harbor, esses Heróis tiveram a responsabilidade de apoiar a participação dos EUA na guerra. A imagem do patriotismo e do espírito de colaboração no momento de guerra foi algo que predominou nos quadrinhos neste período. Um Herói em específico é relevante de ser analisado neste contexto: a Mulher Maravilha. Ela vai representar no momento de guerra a autonomia e a força que a mulher deve ter principalmente no momento em que estas estão assumindo postos no mercado de trabalho, substituindo os homens que agora estão em guerra (JARCEM, 2007). Com o final da guerra, o Macartismo ${ }^{3}$ começa a vigorar dentro dos EUA. Dentro dessa concepção política que predominou no país durante o final da

3 Ver: (HAJDU, 2008). Excelente livro que trata muito bem a questão da imposição do Marcatismo perante a sua visão antagônica frente aos quadrinhos. 
década de 1940 até início da década de 1950, liderados pelo senador Joseph McCarthy. Esse período se caracterizou por uma perseguição total a tudo aquilo que fosse considerado subversivo, e principalmente, de caráter comunista.

Nos Estados Unidos do pós-guerra, muitos poderiam afirmar que não precisavam mais dos heróis. Externamente, imaginar-se-ia que a vida dos estadunidenses estaria confortável. Passava-se a ideia de liberdade, democracia e criticava-se a URSS pelo seu possível aparato repressor. Todavia, Hadju (2008, p. 12) afirma que o cenário interno dos EUA no Pós-Guerra era completamente diferente. Nesse período o xenofobismo, o racismo, desrespeito aos direitos civis, censura à liberdade de expressão, sexismo e perseguições políticas inconstitucionais estavam presentes no dia-a-dia dos EUA. Com tudo isso, ainda assim a existência das armas nucleares, fato que tornava o dia-a-dia da população conturbado. Os quadrinhos, nesse contexto, são considerados subversivos, principalmente os produzidos pela Detective Comics (HAJDU, 2008). Heróis como Batman e Robin são acusados de apologia a homossexualidade, a Mulher Maravilha é colocada como um personagem que deturpa a imagem da mulher. Porém, Jarcem (2007) apresenta uma ideia que pode ser aproveitado para entendermos essa caça aos quadrinhos: ele diz que:

Por causa da irmã de Friedrich Nietzche, os nazistas haviam se apropriado indevidamente de vários 
Cadernos de Clio, Curitiba, n. ${ }^{\circ}$ 3, 2012

conceitos filosóficos deste autor alemão, inclusive o do übermensch que traduzido acaba, de certa maneira sendo similar ao título de Superman, sendo assim, preciso o fim do conflito mundial para que se denunciasse a deturpação do pensamento Nietzchiano e se desfizesse o equívoco que pairava sobre o filósofo alemão. Quando Superman surgiu em cena foi logo colhido pela confusão vigente. As pessoas de esquerda no mundo inteiro, desde o princípio, acusaram-no de ser símbolo do imperialismo norte-americano e, de quebra, da arrogância fascista. Já os políticos linha dura do Partido Republicano viram nele a personificação do tal Superman nazista. Nas palavras dos assessores de Hitler, o Superman não passava de um judeu. (Grifo do autor) (JARCEM, 2007, p: 3-4)

É no contexto de perseguições aos Heróis dos quadrinhos que a tríade mais famosa da DC Comics, (Batman, Super-Homem e Mulher Maravilha) passam a representar cidadãos comuns, ou seja, em alguns casos até perdem seus super-poderes, em outros se limitam a apenas discutir questões familiares, sem nenhum combate a grande vilões, como nos áureos tempos. Se restringem a discutir relacionamentos, a educarem crianças, fazerem tarefas domésticas e ignoram o lado heróico desses personagem (HADJU,2008). Somente com o fim do Marcartismo, em meados da década de 1950, pressionado por uma forte movimentação do meio artístico e jornalístico, surge a necessidade de uma renovação nesses quadrinhos. Com isso, é em 1960 que irá surgir a origem do nosso objeto de estudo: a Liga da Justiça. Reformulando seus heróis, construindo novos e relançando no mercando um novo enredo que 
foi muito bem aceito pelo público, dando início a chamada Era de Prata $^{4}$ dos quadrinhos.

Neste período, Pós-Segunda e início da Guerra Fria, é que os primeiros desenhos animados começam a circular pela televisão aberta estadunidense. Porém, com essa repressão aos heróis ${ }^{5}$ dos quadrinhos, estes encontraram dificuldades para se inserir nessa mídia. Mesmo existido alguns poucos episódios durante este período, somente em 1973 surgia a saga Super Amigos, produzidos pela parceria Hanna-Barbera; e que durou até $1986^{6}$.

Anteriormente a isso ocorreram algumas séries do tipo Live Action sobre o tema, porém carregadas de muito humor e retirando muito a responsabilidade social que os Heróis anteriormente desempenhavam. Este excesso de humor e supressão das críticas sociais acabou com a descaracterização da formulação da ideia de Herói estabelecido com os quadrinhos. Somente em 2001, ocorreu o lançamento dos heróis da DC Comics em desenho animado de larga escala para divulgação em redes televisivas. Anterior a isso, inúmeros filmes e curtas-metragens foram produzidos. Porém, nenhum estabeleceu e recriou os laços tão fortes com os quadrinhos como essa versão. Algumas escolhas e inserções de personagens

\footnotetext{
${ }^{4}$ Sobre isso é interessante analisar uma excelente análise que este disponível em: http://www.universohq.com/quadrinhos/2012/sagasDC.cfm Acesso em: 23/04/2012

${ }^{5}$ Ver o filme: Liga da Justiça: A Nova Fronteira. Escrito e desenhado por Darwyn Cooke (2008).

${ }^{6}$ Sobre isso ver: ALZER \& CLAUDINO, 2006.
} 
acabaram por dar uma contemporaneidade a uma obra do passado ${ }^{7}$. Restabeleceram o diálogo com uma nova geração, mas que continua precisando de Heróis: seja ele o Hulk, Super-Homen, Ben 10 e muitos outros.

\section{Sobre o Ensino de História}

Esta proposta e atividade metodológica de inserção de Desenhos Animados de Super-Herois no Ensino de História, como já foi dito, foi realizado junto ao PIBID. Tendo em vista que nosso objetivo era que os alunos através da observação, analise e pesquisa, conseguissem ver com novos olhos, um olhar mais critico, a sociedade ao qual estão inseridos e os Desenhos Animados, que fazem parte da vida de muitos alunos, mas que muitas vezes tentam, e na maioria conseguem, passar uma mensagem carregada de ideologias. Paulo Freire ratifica isso dizendo: Nosso objetivo é mostrar que o aluno é: "um ser condicionado, mas capaz de ultrapassar o próprio condicionamento." (FREIRE, 1996, p. 129).

Ao trabalhar com essas temáticas, inúmeras dificuldades são encontradas pelo professor, desde problemas como se adaptar ao uso de novas tecnologias seja pela falta de conhecimento, ou até

7 Sobre isso indicamos esta reportagem do site Cosmic Teams formado por críticos e fãs de Quadrinhos e Desenhos Animados que fazem uma excelente analise da Liga da Justiça desde as HQ's até a animação. Disponivel em: <http://www.cosmicteams.com/jla/_docs/artcl-jla-prss-rlse.html> Acesso em: $11 / 02 / 2012$. 
Cadernos de Clio, Curitiba, n. ${ }^{\text {o }}$ 3, 2012

por não saber lidar com novas formas de aprendizagem, muitas vezes, gerando receios de não saber por onde começar quando se quer utilizar essas ferramentas, como constata Belloni (2001). Porém, inúmeros autores, como: Napolitano (2010), Belloni (2001), Castro (2010) e Hagemeyer (2012), os quais fundamentaram esta proposta, defendem a ideia de que o mundo em que vivemos pode ser considerado um mundo visual, no qual a imagem é utilizada para uma Representação mais precisa de tudo o que estamos vivenciando em termos de significação, informação e aprendizagem. Responder a algumas questões que nos permitam interpretar e indagar as fontes, são essenciais. Para qual públicoalvo este desenho foi feito? Por quem e quando foi feito? Qual a intencionalidade desta animação? Essas perguntas, por mais lógicas que possam parecer, são fundamentais para que se possa analisar a fonte de uma maneira segura e extrair dela informações essenciais para fazermos um estudo completo sobre o tema proposto. (NAPOLITANO, 2010)

Evidente que ao trabalhar com essas temáticas em sala de aula inúmeras dificuldades são encontradas, principalmente pela formação que nós alunos e futuros professores estamos tendo nas universidades. Essas mídias, durante o período universitário, são tratadas com estranheza, ou quando são abordadas é de maneira muito superficial, fator que dificulta muito a aplicação e utilização destas em sala de aula (BELLONI, 2001). Este choque foi o 


\section{Cadernos de Clio, Curitiba, n. ${ }^{\circ}$ 3, 2012}

primeiro passo que tentamos romper ao realizarmos esta atividade no PIBID, buscamos estabelecer uma relação maior entre essas mídias e o nossa rotina de bolsista, utilizando mídias como o projetor, computador, internet e celular em nossas aulas, buscando auxiliar as nossas leituras junto a nossa prática.

Os Parâmetros Curriculares Nacionais (PCN's), por exemplo, discutem a importância da inserção de tecnologias contemporâneas de comunicação e informação na escola. Os PCN's apontam que as novas tecnologias sejam desmistificadas e inseridas no contexto escolar, aproximando o professor do aluno e o aluno da escola. Segundo esses Parâmetros, as novas mídias, no caso os desenhos animados, possibilitam ao aluno um desenvolvimento da capacidade não só de analisar, mas também de criticar e interpretar fontes documentais de diversas naturezas, "reconhecendo o papel das diferentes linguagens, dos diferentes agentes sociais e dos diferentes contextos envolvidos em sua produção" (BRASIL, 1998, 74.)

O Programa Institucional de Bolsas de Iniciação a Docência (PIBID - Humanidades - UFPel / CAPES) atua em dois ambientes diferentes, o primeiro é de maneira interdisciplinar, onde bolsistas de várias áreas atuam dentro de uma escola pública propondo intervenções na mesma a fim de melhor a criticidade e o rendimento escolar dos alunos. E o segundo ambiente é ainda dentro da escola, porém são atividades que só dizem respeito a 
nossa área de conhecimento, no caso a disciplina de História. Um dos objetivos e metas estabelecidas em edital pelo PIBID - História da UFPel era o Cine Clube da História. Esse Cine Clube se caracteriza por realizar uma discussão e uma análise critica sobre o filme proposto por nós, bolsistas, ou pelo professor titular da turma; na qual levamos inúmeros elementos, não só do contexto histórico onde foi criado, mas também informações que permitam uma maior compreensão do mesmo, por exemplo, se filme era baseado em um livro mostramos a sinopse deste e etc.

A escola a qual realizamos as atividades foi o Instituto Estadual de Educação Assis Brasil, uma das maiores escolas da região sul do Rio Grande do Sul. Em meados de 2011, mais especificamente no mês de Agosto, o professor nos solicitou que fizemos uma Oficina de História Contemporânea em turno inverso. Esse pedido ocorreu, pois o professor achava que desta maneira os alunos conseguiriam assimilar melhor o conteúdo tendo em vista que os terceiros anos do Ensino Médio na escola possuíam apenas um período de aula por semana. Quando nos deparamos com esta proposta, tínhamos que pensar em uma metodologia que fosse atrativa ao ponto de conseguirmos trazê-los para o turno inverso, pois eles não poderiam perder aula regular na escola. Neste contexto surgiu a ideia de utilizarmos Desenhos Animados como um recurso capaz de exercer essa função que desejávamos. 


\section{Cadernos de Clio, Curitiba, n. ${ }^{\circ}$ 3, 2012}

Todavia, embora o recurso tivesse escolhido, tínhamos um caminho longo para percorrer que era o estabelecimento de uma metodologia. O primeiro momento foi quando nos debruçamos sobre bibliografias que pudessem nos ajudar a pensar uma metodologia que fosse condizente com a realidade que tínhamos em mãos. Essa revisão teórico-bibliográfica ocorreu a autores e conceitos já abordados neste texto. Todavia, utilizamos estes autores como forma de suscitar uma discussão que nos permitisse trabalhar com Desenhos Animados em uma aula de História. Após esse período de leituras, podemos constatar que esse recurso é muito didático, pois sua linguagem caracteriza-se por ser algo mais suave e que trabalha diretamente com o imaginário das pessoas, por isso, foi/é tão utilizado como difusor de ideologias. Carregado de ideologias dissolvidas através de uma linguagem simples, sutil e temperado com humor, o desenho animado mexe com as fantasias das pessoas produzindo uma realidade idealizada, porém não muito distante (FERNANDES, 2003). Outro aprendizado importante sobre imagens em movimento e História foi descobrir que trabalhar com o contexto em que o desenho foi produzido não é apenas preciso, é essencial. A análise do contexto nos permite ver que intencionalidade o autor, roteirista, produtor, animador tem ao realizar sua obra (FERRO, 2010).

Por isso, quando escolhemos a Liga da Justiça (2001), como a animação que iríamos trabalhar na Oficina de História 
Contemporânea $(\mathrm{OHC})$, pensamos que isso facilitaria pelo fato desse desenho ainda estar em circulação na rede aberta da televisão brasileira e ter sido criado num momento que redefiniu a sociedade, tornando ela da maneira como está nos dias atuais: a transição da Guerra Fria para a Guerra ao Terror (HOBSBAWM, 2011). Procuramos trabalhar com eles elementos que surgiram a partir da visualização de alguns episódios ${ }^{8}$. Temas como a questão de gênero, como a participação da mulher, sexualidade, o negro dentro das animações foram levantadas eram nosso principal foco para discutir dentro da História Contemporânea.

A metodologia se desenvolvia em três momentos. O primeiro consistia em discutirmos através de uma exposição de imagens o período histórico ao qual deveríamos trabalhar dentro da OHC. Esse momento caracterizava-se por tentar aguçar a memória dos alunos acerca do que havia sido trabalhado pelo professor anteriormente e relacionando os temas discutidos com o dia-a-dia. O segundo momento era o mais simples. Pois consistia na exibição da animação. Essa parte era mais curta normalmente, pois as animações utilizadas não ultrapassavam 30 minutos de duração. Após os alunos terem assistido a animação, começávamos a parte mais divertida deste momento que era a dinâmica do circulo. Em

8 Episódios: Na Noite Mais Escura Parte 1; Na Noite Mais Escura Parte 2, Injustiça para Todos Parte 1, Dama de Honra Parte 1, Sociedade Secreta Parte 1, No Além Parte 1 e Cartas Parte 1 


\section{Cadernos de Clio, Curitiba, n. ${ }^{\circ}$ 3, 2012}

um circulo, começava-se a debater questões a respeito da animação, que tinha sido assistida, do conteúdo em questão e do cotidiano que pudessem ser levantadas como problemáticas que seriam pesquisadas em casa ou na escola por eles.

Foi solicitado a cada um que pesquisasse sobre o desenho assistido, quem era seu criador, sua produtora, a sua relação (ou não) com os quadrinhos; bem como elementos que foram levantados por eles durante o momento do circulo: questões sobre o motivo do ódio do totalitarismo em alguns episódios da Liga da Justiça, curiosidades sobre a pouca expressão e aparição no Desenho da personagem Mulher-Maravilha e outras questões sobre intolerância e questões étnico-raciais que foram levantadas e todas as 5 turmas em que as oficinas foram realizadas. Bem como a mais debatida questão que é o mito e a simbologia do Heroi, abordando as ideologias presentes na construção deste personagem tão enigmático e ao mesmo tempo apaixonante. A nossa intenção era incentivar a pesquisa em todos os meios possíveis, desde internet, até os Quadrinhos ou qualquer outro meio, porém, cada aluno tinha como meta pesquisar em no mínimo dois suportes diferentes, tentando fazer com que eles saíssem do comodismo da internet.

O receio que tínhamos era de que poucos alunos iriam pesquisar e trazer as informações solicitadas; porém o resultado obtido foi surpreendente. Muitos alunos trouxeram revistas em Quadrinhos que tinha ligação com o assunto, sinopse de outros 
Cadernos de Clio, Curitiba, n. ${ }^{\text {o }}$ 3, 2012

episódios que utilizavam a mesma linguagem entre outras informações das quais nós não esperávamos que fosse acontecer. Então, o ultimo momento desta oficina se caracterizava por mostrar para a turma o que cada um tinha conseguido pesquisar sobre o tema, e depois fazíamos uma discussão sobre o tema. No final pedíamos que cada um fizesse um texto, uma redação, que explicitasse qual a relação da animação vista e o conteúdo estudado. Também pedíamos para que levassem em conta se aquilo transmitido por esta mídia tratava-se de uma verdade ou não. Essa redação servia como forma, não só, de concretizar o conhecimento, mas também de avaliação da nossa prática de ensino.

Após a atividade encerrada, repassávamos ao professor as redações discutíamos e corrigíamos juntos e entregávamos para os alunos, para que estes pudessem ter um registro desta atividade. $\mathrm{O}$ resultado obtido nestas redações foi surpreendente. Muitos relataram que após a Oficina passaram a ver os desenhos animados com outros olhos. Assim, conseguimos estabelecer uma relação mais divertida e dinâmica, para nós, bolsistas-professores, e para os alunos. Com os Heróis conseguimos arrecadar dos alunos informações das quais já traziam consigo. Este conhecimento empírico é uma contribuição muito importante para o Ensino de História e foi através dele que problematizamos a imagem dos Heróis, mostrando a eles as mais variadas versões sobre o tema. Mostrando que, embora seja difícil, é possível realizar atividades 


\section{Cadernos de Clio, Curitiba, n. ${ }^{\circ}$ 3, 2012}

mais lúdicas e que dialoguem com a realidade dos nossos alunos, alertando-os a ver a sociedade com um olhar crítico, tendo consciência de seu lugar dentro dela, tornando-se um agente atuante da História e não um mero observador, além é claro de aprender o conteúdo.

\section{Referências}

Sites:

Disponível em:

http://www.fanboy.com.br/modules.php?name=News\&file=article \&sid=861 Acesso em: 23/04/2012

Disponível em:

http://www.universohq.com/quadrinhos/2012/sagasDC.cfm Acesso em: $23 / 04 / 2012$

Livros:

ALZER, Luiz André; CLAUDINO Mariana. Almanaque Anos 80. São Paulo: Ediouro, 2006.

BACZKO, Bronislaw A imaginação social. In: Enciclopedia Einaudi, Lisboa: Imprensa Nacional, 1985. Pág.. 283-347.

BELLONI, Maria Luiza. O que é mídia-educação. São Paulo: Autores Associados, 2001.

BRASIL, Secretaria de Educação. Parâmetros Curriculares Nacionais. Brasília: MEC, 1998. 
CHARTIER, Roger. A História ou a Leitura no Tempo. São Paulo: Autêntica, 2010.

ECO, Umberto. Apocalípticos e Integrados.São Paulo: Perspectiva, 2004.

FERRO, Marc. Cinema e História. São Paulo: Paz e Terra, 2010. . Filme: uma contra-análise da sociedade? In: LE GOFF, Jacques e NORA, Pierre (Org.). História: novos objetos. Rio de Janeiro: Francisco Alves, 1975. Pág. 199-215

FONSECA, Thais Nívia de Lima e. História \& Ensino de História. Belo Horizonte: Autêntica, 2006.

FUSARI, Maria Felisminda de Resende e. O Educador e o desenho animado que a criança vê na televisão. São Paulo, Edições Loyola, 1985.

HOBSBAWM, Eric. Globalização, Democracia e Terrorismo. São Paulo: Companhia das Letras, 2011.

HAGEMEYER, Rafael Rosa. História \& Audiovisual. Belo Horizonte: Autêntica, 2012.

HAJDU, David. The Ten-Cent Plague: The Great Comic-Book Scare and How It Changed America. New York: Farrar, Straus \& Giroux, 2008.

NAPOLITANO, Marcos. Como usar o cinema na sala de aula. São Paulo: Contexto, 2010.

VIANA, Nildo. Herois e Super-Herois No Mundo Dos Quadrinhos. Rio de Janeiro: Achiamé, 2005. 
Documentários e Filmes:

Liga da Justiça: A Nova Fronteira. Produção e Direção: Darwyn Cooke. New York, DC Comics, 2008. 1 DVD / NTSC, 74 min. Color.

Secret Origin The Story of DC Comics. Produção e Direção: Mac Carter. New York, DC Comics, 2010, 1 DVD / NTSC. 90 min. Color.

Artigos, Teses e Dissertações:

BARROS, José D'assunção. BLOG ESCRITA DA HISTÓRIA. Fonte Histórica: O que é? Disponível em: http://escritasdahistoria.blogspot.com/2011/01/fonte-historicaCASTRO, Nilo André Piana de. Leitura Midiática na Sala de Aula e nos Cursos de Extensão: interpretando e construindo o conhecimento através das imagens em movimento. In: BARROSO, Vera Lúcia Maciel. |et all| (Org.). Ensino de História: Desafio Contemporâneos. Porto Alegre: EST, 2010.

FERNANDES, Adriana Hoffmann. As mediações na produção de sentido das crianças sobre os desenhos animados. Dissertação (Mestrado em Educação). Rio de Janeiro: Pontifícia Universidade Católica, Departamento de Educação, 2003.

JARCEM, René Gomes Rodrigues. História das Histórias em Quadrinhos in: História, imagem e narrativas. n.5, Ano 3, 
Cadernos de Clio, Curitiba, n. ${ }^{\circ}$ 3, 2012

setembro/2007 Diponivel em: http://www.historiaimagem.com.br Acesso em: 12/03/2012. 